The CLASSICAL QUARTERLY and CLASSICAL REVIEW are the Organs of the Classical Association. The QUARTERLY is published in January, April, July, and October;

the REVIEW in the other eight months.

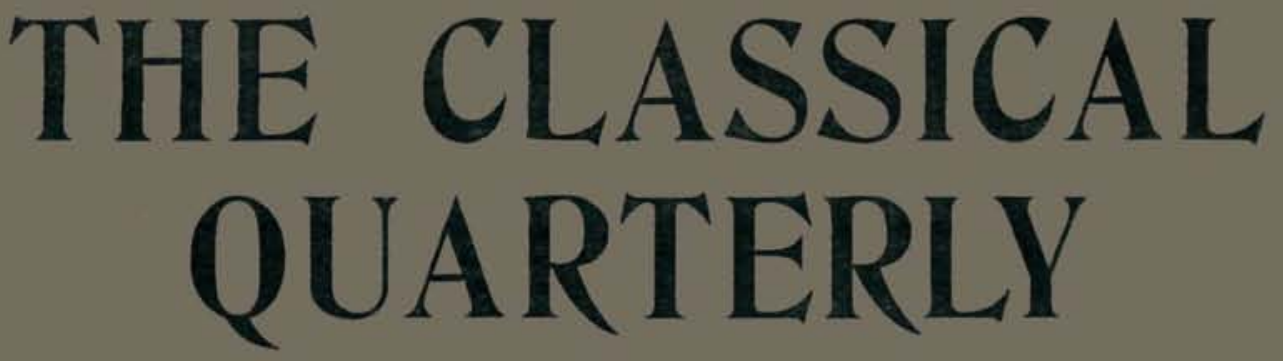

EDITED BY

Profkssor E. V. ARNOLD, Litt.D., Bryn Seiriol, Bangor, N. Wales ; F. W. HALL, M.A., St. John's College, Oxford.

Board of Management:

Prof. R. S. CONWAY, Litt.D., F.B.A., Chairman.

Prot. J. F. DOBSON, M.A, Hon. Treasurer.

Prot. GLIBRT MURRAT,

IL. D. D Litt PBA, F. B S. I With the Chairman, Trea

Prof, C. P.Uitt, F.B.A., F.R.S.L. Jure, ard Semtary, refre

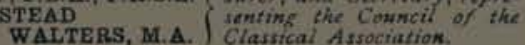

Prof. A. C. OLARK, Litt.D., F.B.A., Hon. Secretary.

CYRIL BAILEY, M.A, Representins the Oxfard Philological Societs.

W. RIDGEWAY, D. LAtt., Litt.D. So.D, It D. F.B.A., Eepresintins the Cambiadge Philotogical Socticty.

With the co-operation of Prof. WM. GARDNer HALe, University of Chicago; Principal Sir WV. Pererson, LL.D., C.M.G., McGill University, Montreal; Prof. T. G. TUCKER, Litt.D., University of Melbourne.

Vol. XIII

\title{
CONTENTS
}

THE SCHERIA OF THE ODISSEY

A. SHBWAN

NOTES ON MARTIAT.

Phagdriana

A. E. Housman

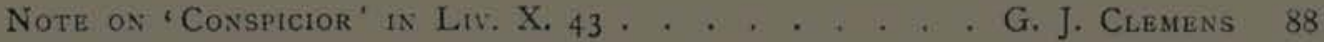

Corrigenda on 'The Analogist and Anomaltst Controversy' F. H. Colson 88

Remarks on the Corpus Glossary . . . . . . . . . . H. Bradley

SUMMARIES OF PERIODICALS:

Literature and General.

LONDON: JOHN MURRAY, ALBEMARLE STREET, W. Boston, MAss. : GINN \& COMPANY, I5, ASHBURTOA ILACE. 


\section{THE CLASSICAL}

QUARTERLY

EDITED BY

PRofessor E. V. ARNOL.D, Litt.D.

AND

F. W. HALL, M.A.

BoARD OF MANAGEMENT:

Prof. R. S. CONWAY, Litt.D., F.B.A., Chairman.

Prof. J. F. DOBSON, M.A., Hon. Treasurer.

Prof. A. C. CLARK, Litt.D., F.B.A., Hon. Secretary.

Prof. GILBERT MURRAY, With the Chairman, Trea-

LL.D., D. Litt., F.B.A., surer, and Secretary repre-

F.R.S.L

Prof. C. FLAMSTEAD WALTERS, M.A. senting the Council of the Classical Association.
CYRIL BAILEY, M.A.,

Representing the Oxford Philologicai Society.

Prof. W. RIDGEWAY, D.Litt., Litt.D., Sc. D., LL.D., F.B.A.

Representing the Cambridge Philological Society.

With the co.operation of Prof. WM. GARDNER HALE, University of Chicago; Sir W. Peterson, LL.D., C.M.G., Montreal; Prof. T. G. TUCKeR, Litt.D., Melbourne.

\section{VOLUME XIII}

PUBLISHED FOR THE CLASSICAL ASSOCIATION BY

JOHN MURRAY, ALBEMARLE STREET, LONDON, W. AND

GINN \& COMPANY, 15, ASHBURTON PLACE, BOSTON, MASS. 


\section{TABLE OF CONTENTS}

No. 1.

PAGE

Actoris in the Odyssey. S. E. BassetT . . . . . . . . . . I

The Scheria of the Odyssey. I. A. Shewan . . . . . . . . 4

Notes on the Ecclesiazusae of Aristophanes. T. L. Agar . . . . . I2

'Puncto tempore.' W. M. LINDSAY . . . . . . . . . . . . 19

Notes on Theocritus. A. S. F. Gow . . . . . . . . . . 20

The Analogist and Anomalist Controversy. F. H. Colson . . . . 24

The Phonetics of MR- in Latin. EDwIN W. FAY . . . . . . 37

On the Meaning of $B A \triangle H N$ and $\triangle P O M \Omega I$ in Greek Historians of the Fifth

Century. W. W. How . . . . . . . . . . 40

Lectio Senatus and Census under Augustus. E. G. Hardy . . . . . 43

Professor Elmore's Hypotheses. E. G. Hardy . • • . . . . 49

'Lombardic.' H. W. Garrod • . • • • • . . . 51

Summaries of Periodicals :

Literature and General $\quad . \quad$. . . . . 53

\section{No. 2.}

The Scheria of the Odyssey. II. A. Shewan . . . . . . . . . $\quad$. 57

Notes on Martial. A. E. Housman . . . . . . . . . . . . 68

Phaedriana. J. P. Postgate . . . . . . . . . . . . . 8

Note on 'conspicior' in Liv. X. 43. G. J. Clemens . . . . . . 88

Corrigenda on 'The Analogist and Anomalist Controversy.' F. H. Colson . 88

Remarks on the Corpus Glossary. H. Bradley . . . . . . . 89

Summaries of Periodicals :

Literature and General . . . . . . . . . . Iog 
Nos. 3, 4.

Ennius and the Punic Wars. EThed M. SteuarT

Some Glosses in the Text of Sophocles. A. C. Pearson . . . . 118

Thucydides on the Third of August, 43 I B.c. J. A. R. MUNRo . . . I 27

Notes on the Greek Rhetors. Herbert W. Greene . . . . . . I 29

Mulier Aries, and other Cruces in Catullus. O. L. RICHMond . . . . . I 34

The Greek Adjectives ending in $\eta \mathbf{s}$. RODERICK MCKenZIE . . . . 141

Siparım and Supparus. A. E. Housman . . . . . . . . . . . I49

Euripides, Rhesus 720. Arthur Platt . . . . . . . . . . . . . I53

Notes on the Birds of Aristophanes, T. L. AGAR . . . . . . . . . . $\quad$ I 55

Plato, Republic 421 4 . A. S. Ferguson . . . . . . . . . . . . . 163

A Ninth Century Commentary on Phocas. M. Esposito . . . . . 166

Aleuas and Alea. Grace Harriet Macurdy . . . . . . . . I IO

Lucan I 99-103. J. S Phillimore . . . . . . . . . . . . 172

On Lucretius II. 355-36o. W. A. MerRILL . . . . . . . . . 173

Summaries of Periodicals:

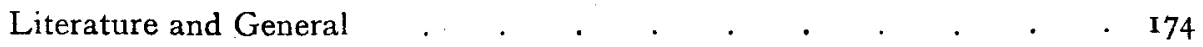

INDICES to VoL. XIII. . . . . . . . . . . . . . . I8I

Alteration of Price.-Owing to the increase in the cost of materials, the price of cases for binding volumes of the CLASSICAL QuarTeRLY is advanced to 2s. 6d. These may be obtained from any bookseller; postage $4 d$. extra. 